\title{
Association of Ammodramus bairdii A. 1844, and Other Species of Grassland Granivorous Birds in Winter Time in Northwestern Mexico
}

\author{
Jose Hugo Martinez-Guerrero', Martin Emilio Pereda-Solis ${ }^{1}{ }^{*}$, Christian Wehenkel2 \\ ${ }^{1}$ Facultad de MedicinaVeterinaria y Zootecnia. Universidad Juarez del Estado de Durango, Durango, Mexico \\ ${ }^{2}$ Instituto de Silvicultura e Industria de la Madera, Universidad Juarez del Estado de Durango, Durango, \\ Mexico \\ Email: che hugo1@hotmail.com, ${ }^{*}$ conplandg@hotmail.com, wehenkel@ujed.mx
}

Received 27 February 2014; revised 27 March 2014; accepted 5 April 2014

Copyright (C) 2014 by authors and Scientific Research Publishing Inc.

This work is licensed under the Creative Commons Attribution International License (CC BY). http://creativecommons.org/licenses/by/4.0/

c) (i) Open Access

\section{Abstract}

During the winter of $\mathbf{2 0 0 9}$ grassland birds were monitored in the region of Cuchillas de la Zarca to estimate the association between Ammodramus bairdii Audubon 1844, focal species of grassland and bird species belonging to the trophic guild of grassland granivorous birds $(n=25)$. The study area was divided into monitoring quadrants $(n=16)$ where 96 transects for bird monitoring were conducted, recording 16,635 individuals of which only $32.9 \%$ were in the trophic guild of grassland granivorous birds. The association between $A$. bairdii and other species was estimated from the nonparametric statistical index of Kendall's coefficient of concordance $(W)$ and the $p$ value, through permutation analysis $(n=10,000)$, finding positive and significant associations $(p \leq 0.05)$ of the target species for study with Sturnella magna, Passerculus sandwichensis and Ammodramus savannarum, species that share habitat preferences of natural grassland in good condition, slightly grazed and with little tolerance to the shrub cover. The association $W$ ranged from 0.072 and 0.749. These results can recognize this region as an important area for the conservation of obligate grassland birds during winter, suggesting establish training programs to better utilize this resource by means of cattle activity.

\section{Keywords}

Grassland Birds, Kendall Coefficient, Baird's Sparrow, Winter Monitoring

\footnotetext{
"Corresponding author.

How to cite this paper: Martinez-Guerrero, J.H., Pereda-Solis, M.E. and Wehenkel, Ch. (2014) Association of Ammodramus bairdii A. 1844, and Other Species of Grassland Granivorous Birds in Winter Time in Northwestern Mexico. Open Journal of Ecology, 4, 281-288. http://dx.doi.org/10.4236/oje.2014.45026
} 


\section{Introduction}

The grassland is the most threatened ecosystem of the earth. There are various causes explaining this: agricultural intensification, urbanization, energy development, expansion of invasive species [1]. Consequently, and for a few decades, the grassland bird populations have declined continuously [2].

These facts become important when the habitat for several obligate grassland bird species is broken or lost [3] and it becomes a critical factor in conserving birds/habitat when such changes occur in both "working" lands as wintering grounds. With regard to this, recent work [4] has stated that $88 \%$ of grassland bird species breed in the Great Plains of North America and $90 \%$ of them spend winter in the Chihuahuan Desert, giving a clear idea of the magnitude of the problem.

Within this group of birds there are some species whose populations have declined to a greater degree than others, where currently efforts are made between Canada, the US and Mexico to expand the knowledge about them and develop proposals for their preservation [5] [6].

This is the case of the Baird's sparrow (Ammodramus bairdii) which is one of the grassland bird species that has a strong negative trend $(-3.0 \%$ per year) in its population [2], of which there is not sufficient information of its stay at winter lands, particularly in Mexico [7], where the increase of the agricultural frontier and the lowtech extensive cattle raising cause reduction of grassland areas [8].

In that sense, abundance and distribution of Ammodramus bairdii [9] [10] as well as other 49 obligate grassland bird species such as Anthus spragueii, Calcarius ornatus, Ammodramus savannarum, Pooecetes gramineus, is taken as a priority; they require native grasslands in good condition by taking the structure of vegetation as a key element in research [11]-[14].

These sparrows and other wintering birds depend almost entirely on the seeds of plants in their diet to survive the winter months [15] [16]. Therefore, the availability of seeds in the soil has a direct impact on the composition and dynamics of bird communities during winter.

However, little effort has been made to know how this species can be associated with others of similar behavior and conditions of habitat [17], in Mexico and in winter season [18].

Therefore the objective of this study was to determine the association of Ammodramus bairdii, with other species of grassland granivores that share the winter habitat in the Cuchillas de la Zarca region of northwestern Mexico, to increase awareness of species whose populations decline annually and help to highlight the importance of the region for the preservation of this and other obligate grassland wintering birds.

\section{Methodology}

\subsection{Study Area}

The study area was located in the priority region for preservation of grassland (APCP) called Cuchillas de la Zarca [5] (Figure 1), and is part of the Chihuahuan Desert. It comprises the southern state of Chihuahua and the northern state of Durango, Mexico, with an area of $6297 \mathrm{~km}^{2}$, between the geographical coordinates $105^{\circ} 04^{\prime} 30.86^{\prime \prime} \mathrm{W}$ and $24^{\circ} 41^{\prime} 41.28^{\prime \prime} \mathrm{N}$ and $104^{\circ} 57^{\prime} 07.48^{\prime \prime} \mathrm{W}$ and $25^{\circ} 27^{\prime} 04.24^{\prime \prime} \mathrm{N}$.

Vegetation consists of xeric scrub (91\%), and natural grasslands (9\%) [19], where the shrub layer consisted of the genera: Larrea, Prosopis, Acacia, Ephedra, Nolina and Opuntia, Juniperus and Quercus, the herbaceous layer consisted of genera: Bouteloa, Aristida, Buchloe, Andropogon, Muhlenbergia, Sporobolus, Heteropogon, Pleuraphis.

The average altitude of the area is $1850 \mathrm{~m}$ asl, in the study grassland of private and municipal properties were included and temperature of the coldest month was $-3^{\circ} \mathrm{C}$ to $18^{\circ} \mathrm{C}$.

A GIS was used to build a mesh of squares (Figure 1) of $18 \mathrm{~km}$ per side covering the entire surface of APCP, of all quadrants $(\mathrm{N}=36)$, those where natural grassland is present $(\mathrm{n}=16)$ were selected. In those where there are available roads (over $5 \mathrm{~km}$ ), sampling points (Figure 2) were located every $500 \mathrm{~m}$, which received a random number, so that in the first three (1-3) transects were carried out for bird monitoring [20].

Methodology for bird monitoring [20] consisted of two observers trained to recognize grassland birds in paired transects, walking tours of a mile were made, one-time, with support from a GPS Garmin Etrex ${ }^{\circledR}$.

At each sampling point observers walked perpendicularly to the road, using $8 \times 42$ binoculars, and species and number of birds observed were recorded. Monitoring was conducted between January 20 and February 21, 2009, between 08:00 and 12:00 each day, and then we brought together the Ammodramus bairdii (AMMBAI) 


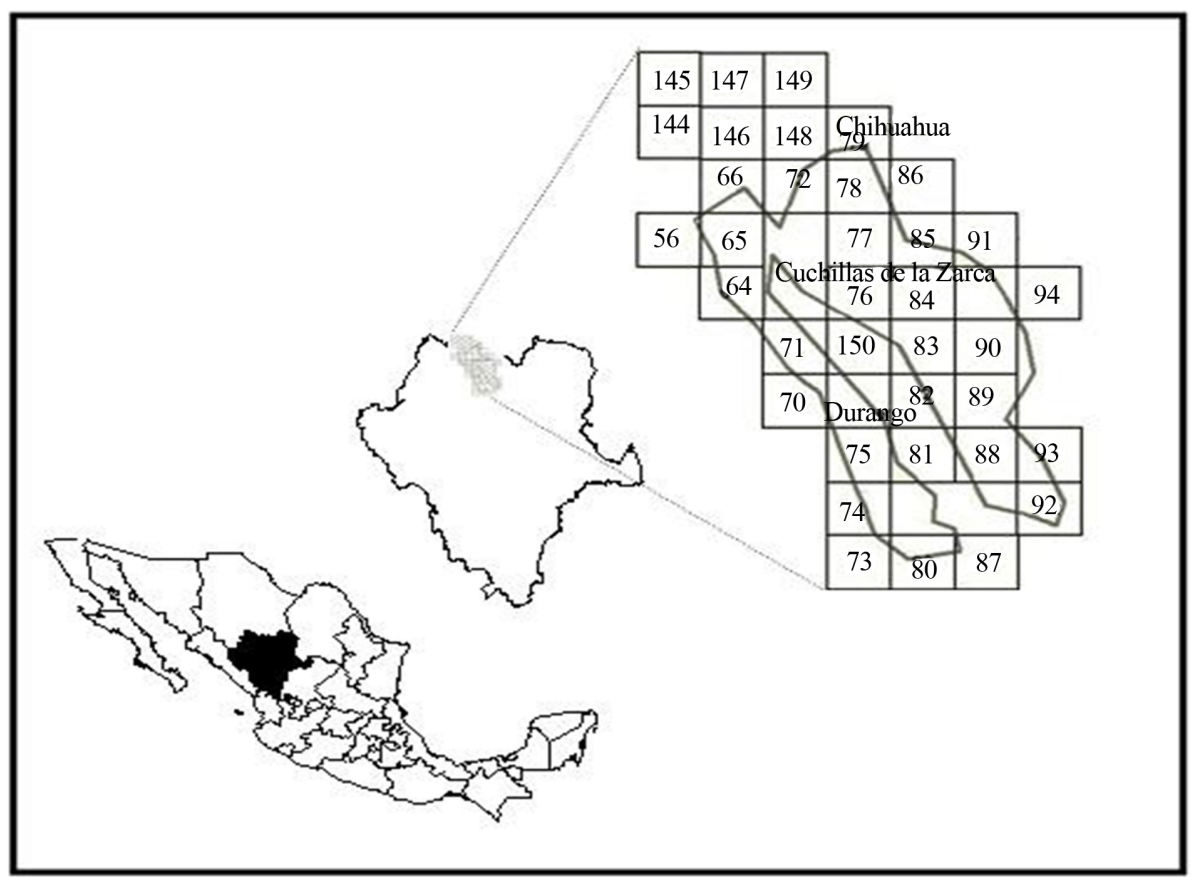

Figure 1. Location of the priority region for grassland conservation in Cuchillas de la Zarca.

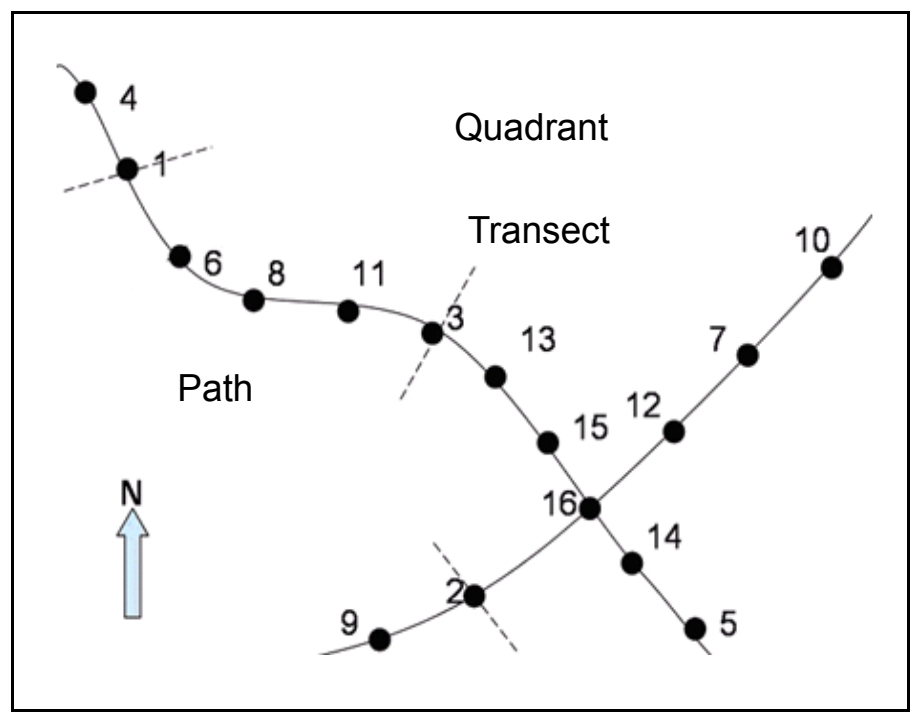

Figure 2. Quadrant sample with points and paired transects.

and the trophic guild species of grassland granivores using the four-letter code [21], placing number of birds per species per monitored quadrant.

\subsection{Statistical Analysis}

The measure of association between AMMBAI and granivorous grassland bird species was performed using the nonparametric statistic Kendall's coefficient of concordance $(W)$. This is a normalization of the Friedman statistical test, and can be used to measure the degree of concordance between different trials that are assumed to a group or $\mathrm{n}$ objects. For the present study they are represented by bird species [22].

The close relationship between the Spearman's $r_{s}$ correlation coefficient and $W$ was used to calculate the Kendall's statistics, where $W$ can be calculated directly from the mean $(\bar{r})$ of Spearman $\left(r_{s}\right)$ paired correlations 
from the following relationship [22]-[24]:

$$
W=((p-1) \bar{r}+1) / p
$$

where $p$ is the number of variables among which the Spearmen correlation coefficients are calculated. For the case of the two $W$ variables it is a linear transformation of $r_{s}: W=\left(r_{s}+1\right) / 2$.

Equation (1) shows that trials can only be concordant if the Spearman correlation is positive, two trials having perfectly opposite ranges for a group of objects have a negative correlation $r_{s}=-1$, therefore $W=0$, which means that there is no concordance [22].

Permutation analysis was used to verify that the observed associations $(W)$ are or are not random results. For this situation, a test of permutations of $W$ for two variables is the exact equivalent of a permutation test of $r_{s}$ for the same variables. The significant probabilities ( $p$ value) were obtained in terms of the proportion of permutations for which the association was measured, above their observed values. On this basis, the observed values of $W$ may be interpreted as highly significant or significantly small if $p$ is lower than 0.05 or higher than 0.95 , respectively. For both cases, it is assumed that forces which do not depend on random are involved in the observed associations [22] [25] [26].

The parametric statistics of data from birds was performed using the SAS ${ }^{\circledR}$ PROC UNIVARIATE.

\section{Results and Discussion}

Ninety six transects were carried out in the winter of 2009 in the APCP of Cuchillas de la Zarca for bird monitoring. Each transect was $1 \mathrm{~km}$ long, 6 transects per quadrant $(\mathrm{n}=16)$, recording 16,635 birds distributed in 31 families of 63 genera and 79 different species, of which 26 (32.9\%) were located within the trophic guild of grassland granivores to a total of 7257 individuals.

The relative abundance values (Table 1) place this region (APCP) as the most important in the Chihuahuan desert for many species of migrant birds by their diversity and it is first in winter abundance of Ammodramus bairdii [27].

The results of the estimation of Kendall's coefficient of concordance (W) between the abundance of Ammodramus bairdii and the other 25 species of granivorous grassland birds are presented in Table 2.

The analysis of the calculation of the association by Kendall concordance index (W) between Baird's sparrow and 25 species of birds belonging to the trophic guild of grassland granivores shows different values of association, although they share the same habitat, birds of different species establish distinct patterns of movements between wintering birds, as [28] found in Arizona.

Association values found of $W$ vary between 0.272 and 0.749 , but only 3 of these associations (12\%) were positive and significant $(\mathrm{p} \leq 0.05)$.

Reference [29] states in his study on the influence of seed availability in shaping the diet and winter habitat selection in bird communities of arid grassland that between bird species there is preference for different seeds, where size, shape, and energy content affect how the habitat is shared by birds, so the association between granivorous species can be explained by this fact.

In this respect the found association with eastern meadowlark (Sturnella magna) was the highest and explained by the preference of this species for native grasslands in good condition with plenty of organic matter in the soil [30], habitat characteristics that shares with Baird's sparrow [27] [31]-[33].

Similarly, the Ammodramus bairdii was associated with Passerculus sandwichensis although there are differences in foraging and behavior of both species [34], perhaps because they prefer just as Baird's sparrow open habitats with shortly grazed natural grasslands [35].

The association with Ammodramus savannarum can be explained because both species avoid grasslands with extensive shrub covers [36] and prefer plant associations dominated by the genera Bouteloa and Aristida ssp. [29], such as those found in the study area.

For other species the calculation of the association was not statistically significant, since most of them have higher tolerance than Baird's sparrow to plant structures with less coverage of natural grasslands and greater shrub coverage [34] [37] [38].

\section{Conclusions}

The association between Baird's sparrow and other 25 species of granivorous grassland birds in the region of 
Table 1. Bird abundance of granivorous guild species in the region of Cuchillas de la Zarca, 2009.

\begin{tabular}{|c|c|c|c|c|c|}
\hline Species & $\mathrm{Key}^{\mathrm{a}}$ & $\mathrm{N}$ & Average $^{b}$ & Standard error ${ }^{\mathrm{b}}$ & Abundance \% \\
\hline Aimophila boterii & AIMBOT & 1 & 0.06 & 0.06 & 0.013 \\
\hline Aimophila cassinii & AIMCAS & 7 & 0.43 & 0.18 & 0.096 \\
\hline Aimophila ruficeps & AIMRUF & 7 & 0.43 & 0.32 & 0.096 \\
\hline Ammodramus bairdii & AMMBAI & 49 & 3.05 & 0.52 & 0.675 \\
\hline Ammodramus savanarum & AMMSAV & 80 & 5 & 0.98 & 1.102 \\
\hline Amphispiza bileniata & AMPBIL & 119 & 7.43 & 3.87 & 1.639 \\
\hline Anthus spragueii & ANTSPR & 40 & 2.50 & 0.63 & 0.551 \\
\hline Calamospiza melanocorys & CALMEL & 3 & 0.18 & 0.13 & 0.041 \\
\hline Calcarius ornatus & CALORN & 936 & 58.50 & 30.88 & 12.897 \\
\hline Callipepla squamata & CALSQU & 126 & 7.87 & 3.84 & 1.736 \\
\hline Carpodacus mexicanus & CARMEX & 11 & 0.68 & 0.28 & 0.151 \\
\hline Chondestes gramacus & CHOGRA & 326 & 20.37 & 11.83 & 4.492 \\
\hline Eremophila alpestris & EREALP & 6 & 0.37 & 0.27 & 0.082 \\
\hline Melospiza linconlii & MELLIN & 9 & 0.56 & 0.28 & 0.124 \\
\hline Molothrus ater & MOLATE & 42 & 2.62 & 2.62 & 0.578 \\
\hline Passerculus sandwichsensis & PASSAN & 417 & 20.06 & 6.45 & 5.746 \\
\hline Pipilo fuscus & PIPFUS & 49 & 3.06 & 0.85 & 0.675 \\
\hline Pooecetes gramineus & POOGRA & 1607 & 100.43 & 22.32 & 22.144 \\
\hline Spizella breweri & SPIBRE & 692 & 43.25 & 12.71 & 9.535 \\
\hline Spizella palida & SPIPAL & 148 & 9.25 & 4.18 & 2.039 \\
\hline Spizella passerina & SPIPAS & 1871 & 116.93 & 20.64 & 25.782 \\
\hline Sturnella magna & STUMAG & 149 & 9.31 & 1.61 & 2.053 \\
\hline Sturnella neglecta & STUNEG & 22 & 1.37 & 0.49 & 0.303 \\
\hline Zenaida asiatica & ZENASI & 57 & 3.56 & 2.18 & 0.785 \\
\hline Zenaida macroura & ZENMAC & 481 & 30.06 & 5.96 & 6.628 \\
\hline Zonotrichia leucoprys & ZONLEU & 2 & 0.12 & 0.08 & 0.027 \\
\hline
\end{tabular}

a: Keys of six characters, International Nomenclatura, AOU, 2009. http://www.birdpop.org/AlphaCodes.htm, b: Calculated by SAS $®$ PROC UNIVARIATE.

Cuchillas deZarca during winter season, using the Kendall's concordance index (W) showed that there are differences between birds that use seeds as the only source of food.

The results highlighting the association between $A$. bairdii and S. magna, P. sandwichensis and A. savannarum show consistency and biological explanation since all of these species share preferences for common habitat characteristics, such as natural grasslands in good condition, slightly grazed, small areas of bare soil and low presence of bushes. 
Table 2. Association $(W)$ between AMMBAI and bird species of granivorus trophic guild of grassland in Cuchillas de la Zarca, 2009.

\begin{tabular}{|c|c|c|}
\hline AMMBAI/species & Asociation (W) & $p$ Value \\
\hline AMMBAI/SPIBRE & 0.431 & 0.30 \\
\hline AMMBAI/PIPFUS & 0.520 & 0.44 \\
\hline AMMBAI/AIMCAS & 0.655 & 0.12 \\
\hline AMMBAI/CALORN & 0.513 & 0.46 \\
\hline AMMBAI/SPIPAS & 0.544 & 0.37 \\
\hline AMMBAI/STUMAG & 0.749 & $0.02^{\mathrm{a}}$ \\
\hline AMMBAI/EREALP & 0.350 & 0.14 \\
\hline AMMBAI/CALMEL & 0.379 & 0.20 \\
\hline AMMBAI/CHOGRA & 0.403 & 0.23 \\
\hline AMMBAI/ZENMAC & 0.615 & 0.29 \\
\hline AMMBAI/PASSAN & 0.723 & $0.04^{\mathrm{a}}$ \\
\hline AMMBAI/ANTSPR & 0.635 & 0.14 \\
\hline AMMBAI/POOGRA & 0.311 & 0.07 \\
\hline AMMBAI/AMPBIL & 0.424 & 0.28 \\
\hline AMMBAI/AMMSAV & 0.728 & $0.03^{\mathrm{a}}$ \\
\hline AMMBAI/SPIPAL & 0.359 & 0.13 \\
\hline AMMBAI/STUNEG & 0.617 & 0.18 \\
\hline AMMBAI/ZENASI & 0.538 & 0.38 \\
\hline AMMBAI/AIMRUF & 0.272 & 0.07 \\
\hline AMMBAI/CALSQU & 0.628 & 0.17 \\
\hline AMMBAI/ZONLEU & 0.538 & 0.39 \\
\hline AMMBAI/MOLATE & 0.588 & 0.25 \\
\hline AMMBAI/AIMBOT & 0.472 & 0.41 \\
\hline AMMBAI/CARMEX & 0.338 & 0.11 \\
\hline AMMBAI/MELLIN & 0.459 & 0.37 \\
\hline
\end{tabular}

a: Associations with values of $p \leq 0.05$ are significant.

This suggests establishing training programs for owners of pastures and promotes appropriate use by extensive cattle raising, where better grass produces best cattle and represents best habitat for obligate grassland bird species.

In addition to suggesting continue with these studies using the same methodology, it should be added the possibility to quantify the availability of seed on the ground, to better explain these results.

\section{References}

[1] Hoekstra, J.M., Boucher, T.M., Ricketts, T.H. and Roberts, C. (2005) Confronting a Biome Crisis: Global Disparities of Habitat Loss and Protection. Ecology Letters, 8, 23-29. http://dx.doi.org/10.1111/j.1461-0248.2004.00686.x

[2] Sauer, J.R., Hines, J.E., Fallon, J., Pardieck, K.L., Ziolkowski, D.J. and Link, W.A. (2011) The North American Breeding Bird Survey, Results and Analysis 1966-2010, version 12.07.2011. US Geological Survey Patuxent Wildlife Research Center, Laurel, Maryland. 
[3] Brennan, L.A. and Kuvlesky, W.P. (2005) North American Grassland Birds: An Unfolding Conservation Crisis? Journal of Wildlife Management, 69, 1-13. http://dx.doi.org/10.2193/0022-541x(2005)069\%3C0001:nagbau\%3E2.0.co;2

[4] Pool, B.D., Panjabi, A., Macias-Duarte, A. and Soljhem, D. (2014) Rapid Expansion of Croplands in Chihuahua, Mexico Threatens Declining North American Grassland Bird Species. Biological Conservation, 170, 274-281 http://dx.doi.org/10.1016/j.biocon.2013.12.019

[5] CEC and TNC (2005) North American central grasslands priority conservation areas: technical report and documentation. In: Karl, J.W. and Hoth, J., Eds., Commission for Environmental Cooperation and The Nature Conservancy, Montreal, Quebec.

[6] Berlanga, H., Kennedy, J.A, Rich, T.D., Arizmendi, M.C., Beardmore, C.J., Blancher, P.J., Butcher, G.S., Couturier, A.R., Dayer, A.A, Demarest, D.W., Easton, W.E., Gustafson, M., Iñigo-Elias, E., Krebs, E.A, Panjabi, A.O., Rodriguez-Contreras, V., Rosenberg, K.V., Ruth, J.M., Santana-Castellon, E., Vidal, R.Ma. and Will, T. (2010) Conservando a Nuestras aves compartidas: la vision trinacional de Compañeros en Vuelo para la conservación de las aves terrestres. Cornell Lab. of Ornithology: Ithaca, N.Y. USA, 49 pp.

[7] Dechant, J.A., Sondreal, M.L., Johnson, D.H., Igl, L.D., Goldade, C.M., Nenneman, M.P. and Euliss, B.R. (2003) Effects of Management Practices on Grassland Birds: Baird's Sparrow. Northern Prairie Wildlife Research Center, Jamestown.

[8] Curtin, C., Sayre, N. and Lane, B. (2002) Transformations of the Chihuahuan Borderlans: Grazing, Fragmentation and Conservation in Desert Grasslands. Enviromental Science \& Policy, 5, 55-68. http://dx.doi.org/10.1016/s1462-9011(02)00020-5

[9] Ahlering, M.A., Johnson, D.H. and Faaborg, J. (2009) Factors Associated with Arrival Densities of Grasshopper Sparrow (Ammodramus savannarum) and Baird's Sparrow (A. bairdii) in the Upper Great Plains. The Auk, 126, 799-808. http://dx.doi.org/10.1525/auk.2009.08154

[10] Martinez-Guerrero, J.H., Wehenkel, C., Pereda, M.E., Panjabi, A., Levandoski, G., Corral, R. Diaz, J. and Hernández, J. (2011) Abundancia y distribución invernal de Ammodramus bairdii, en la región de cuchillas de la zarca, México. Hutzil, Revista Mexicana de Ornitología, 12, 9-14

[11] Levandoski, G., Panjabi, A. and Sparks, R. (2008) Wintering Bird Inventory and Monitoring in Priority Conservation Areas in Chihuahuan Desert Grasslands in Mexico: 2008 results. Rocky Mountain Bird Observatory, Brighton, CO, Final Technical Report I-MXPLAT-TNC08-02.

[12] Fisher, J.R. and Davis, S.K. (2010) From Wiens to Robel: A Review of Grassland-bird Habitat Selection. Journal of Wildlife Management, 74, 265-273. http://dx.doi.org/10.2193/2009-020

[13] Panjabi, A., Youngberg, E. and Levandoski, G. (2010) Wintering Grassland Bird Density in Chihuahuan Desert Grassland Priority Conservation Areas, 2007-2010. Rocky Mountain Bird Observatory, Brighton, CO, RMBO Technical Report I-MXPLAT-08-03. 83 pp.

[14] Macias-Duarte, A. and Panjabi, A. (2013) Association of Habitat Characteristics with Winter Survival of a Declining Grassland Bird in Chihuahuan Desert Grasslands of Mexico. The Auk, 130, 141-149. http://dx.doi.org/10.1525/auk.2012.12047

[15] Grzybowski, J. A. (1983) Sociality of Grassland Birds During winter. Behavioral Ecology and Sociobiology, 13, 211219. http://dx.doi.org/10.1007/bf00299925

[16] Desmond, M.J., Mendez-Gonzalez, C. and Abbott, L.B. (2008) Winter Diets and Seed Selection of Granivorous Birds in Southwestern New Mexico. In: Ruth, J.M., Brush, T. and Krueper, D.J., Eds., Birds of the US-Mexico Borderlands: Distribution, Ecology, and Conservation, Studies of Avian Biology, 37, 101-112.

[17] Knopf, F.L. (1994) Avian Assemblages on Altered Grasslands. Studies of Avian Biology, 15, 247-257

[18] Vickery, P.D. and Herkert, J.R. (2001) Recent Advances in Grassland Bird Research: Where Do We Go from Here? The Auk, 118, 11-15. http://dx.doi.org/10.1642/0004-8038(2001)118[0011:raigbr]2.0.co;2

[19] Rzedowski, J. (1981) Vegetación de México. LIMUSA. México.

[20] Panjabi, A., Levandoski, G., and Sparks, R. (2007) Wintering Bird Inventory and Monitoring in Priority Conservation Areas in Chihuahuan Desert Grasslands in Mexico: 2007 pilot results. Rocky Mountain Bird Observatory, Brighton, CO. Final Technical report I-MXPLAT-TNC07-02. $54 \mathrm{pp}$.

[21] Pyle, P. and DeSante, D.F. (2003) Four-Letter and Six-Letter Alpha Codes for Birds Recorded from the American Ornithologists' Union Check-List Area. North American Bird Bander, 28, 64-79.

[22] Legendré, P. (2005) Species Associations: The Kendall Coefficient of Concordance Revisited. Journal of Agricultural, Biological, and Environmental Statistics, 10, 226-245. http://dx.doi.org/10.1198/108571105x46642

[23] Siegel, S. and Castellan Jr., N.J. (1988) Nonparametric Statistics for the Behavioral Sciences. 2nd Edition, McGraw- 
Hill, New York. http://dx.doi.org/10.1177/014662168901300212

[24] Zar, H.J. (1999) Biostatistical Analysis. 4th Edition, Prentice Hall, Upper Saddle River.

[25] Manly, B.F.J. (1997) Randomization, Bootstrap and Monte Carlo Methods in Biology. Chapman and Hall, London.

[26] Wehenkel, C., Bergmann, F. and Gregorius, H.R. (2007) Interactions between Genetic Structures and Species Composition in Forest Tree Communities. Silvae Genetica 56, 3-4, 101-110.

[27] Macias-Duarte, A., Panjabi, A., Pool, D., Youngberg, E. and Levandoski, G. (2011) Wintering Grassland Bird Density in Chihuahuan Desert Grassland Priority Conservation Areas, 2007-2011. Rocky Mountain Bird Observatory, Brighton, CO, RMBO Technical Report I-MXPLAT-10-01, 164 p.

[28] Gordon, C.E. (2000) Movement Patterns of Wintering Sparrows in Arizona. The Auk, 117, 748-759. http://dx.doi.org/10.2307/4089599

[29] Mendez-Gonzalez, C. (2010) Influence of Seed Resources on the Diet, Seed Selection and Community Dynamics of Wintering Birds in Semi-Arid Grasslands. Ph.D. Thesis, New Mexico State University, Las Cruces, New Mexico.

[30] Lanyon, W.E. (1995) Eastern Meadowlark (Sturnella magna). In: Poole, A., Ed., The Birds of North America Online, Cornell Lab of Ornithology, Ithaca. http://dx.doi.org/10.2173/bna.160

[31] Davis, S.K. (2004) Area Sensitivity in Grassland Passerines: Effects of Patch Size, Patch Shape and Vegetation Structure on Bird Abundance and Occurrence in Southern Saskatchewan. The Auk, 121, 1130-1145. http://dx.doi.org/10.2307/4090481

[32] Martinez-Guerrero, J.H., Wehenkel, C., Pereda, M.E., Corral, J.J., Rosales, F. and Herrera, H. (2010) Measuring Associations between Granivorous grassland Birds Species and between the Bird Species and Winter Habitat in Northwestern Mexico. Research Journal of Biological Sciences, 5, 713-721. http://dx.doi.org/10.3923/rjbsci.2010.713.721

[33] Martinez-Guerrero, J.H., Wehenkel, C., Pereda-Solis, M.E., Panjabi, A., Levandoski, G., Corral-Rivas, J. and DiazMoreno, R. (2011) Relationships between Ammodramus bairdii, Audubon 1844, Soil Cover and Attributes of Winter Vegetation in Northwestern Mexico. Agrociencia, 45, 443-451.

[34] Ginter, D.L. and Desmond, M.J. (2005) Influence of Foraging and Roosting Behavior on Home-Range Size and Movement Patterns of Savannah Sparrows wintering in South Texas. Wilson Bulletin, 117, 63-71. http://dx.doi.org/10.1676/04-017

[35] Wheelwright, N.T. and Rising, J.D. (2008) Savannah Sparrow (Passerculus sandwichensis). In: Poole, A., Ed., The Birds of North America Online, Cornell Lab of Ornithology, Ithaca. http://bna.birds.cornell.edu.bnaproxy.birds.cornell.edu/bna/species/045

[36] Vickery, P.D. (1996) Grasshopper Sparrow (Ammodramus savannarum). In: Poole, A., Ed., The Birds of North America Online, Cornell Lab of Ornithology, Ithaca. http://bna.birds.cornell.edu.bnaproxy.birds.cornell.edu/bna/species/239

[37] Dunne, P. (2006) Pete Dunne's Essential Field Guide Companion. Houghton Mifflin Harcourt, New York.

[38] Koper, N., Walker, D.J. and Champagne, J. (2009) Nonlinear Effects of Distance to Habitat Edge on Sprague's Pipits in Southern Alberta, Canada. Landscape Ecology, 24, 1287-1297. http://dx.doi.org/10.1007/s10980-009-9375-3 